\title{
Three decades of research on O-GlcNAcylation - a major nutrient sensor that regulates signaling, transcription and cellular metabolism
}

\section{Gerald W. Hart*}

Department of Biological Chemistry, School of Medicine, Johns Hopkins University, Baltimore, MD, USA

\section{Edited by:}

Tony Lefebvre, University Lille 1, France

Reviewed by:

Tarik Issad, University Paris Descartes, France

Tony Lefebvre, University Lille 1, France

*Correspondence:

Gerald W. Hart, Department of Biological Chemistry, School of Medicine, Johns Hopkins University, WBSB515, 725 North Wolfe Street, Baltimore, MD 21205-2185, USA e-mail:gwhart@jhmi.edu
Even though the dynamic modification of polypeptides by the monosaccharide, O-linked $\mathrm{N}$-acetylglucosamine (O-GIcNAcylation) was discovered over 30 years ago, its physiological significance as a major nutrient sensor that regulates myriad cellular processes has only recently been more widely appreciated. O-GIcNAcylation, either on its own or by its interplay with other post-translational modifications, such as phosphorylation, ubiquitination, and others, modulates the activities of signaling proteins, regulates most components of the transcription machinery, affects cell cycle progression and regulates the targeting/turnover or functions of myriad other regulatory proteins, in response to nutrients. Acute increases in O-GIcNAcylation protect cells from stress-induced injury, while chronic deregulation of $O$-GlcNAc cycling contributes to the etiology of major human diseases of aging, such as diabetes, cancer, and neurodegeneration. Recent advances in tools to study O-GIcNAcylation at the individual site level and specific inhibitors of $O$-GIcNAc cycling have allowed more rapid progress toward elucidating the specific functions of O-GlcNAcylation in essential cellular processes.

Keywords: O-GIcNAcylation, O-GIcNAc transferase, O-GIcNAcase, signaling, transcription, diabetes, cancer, Alzheimer's disease

\section{EARLY HISTORY}

O-GlcNAcylation was discovered in the early 1980s when bovine milk galactosyltransferase was used as an enzymatic probe of terminal $N$-acetylglucosamine moieties in cells of the murine immune system (1). Later studies established $O$-GlcNAc's surprising nucleocytoplasmic subcellular localization and distribution at a time when dogma stated that protein glycosylation only occurs within the secretory pathway or extracellular compartments (2). O-GlcNAcylation was shown to be highly abundant within the nucleus and particularly enriched at the nuclear envelope and on nuclear pore proteins (3-5). However, O-GlcNAcylation was also found to be abundant on cytoskeletal proteins of human erythrocytes, which lack a nucleus (6). Viruses were also found to contain O-GlcNAcylated proteins, which occur on proteins surrounding their nucleic acid cores, rather than on their capsids, where other forms of "classical" protein glycosylation are found (7). O-GlcNAcylation was subsequently found to be highly enriched on proteins associated with chromatin in Drosophila (8), and $O$-GlcNAc was shown to not only be a major modifier of transcription factors (9), but also a major modification of the Cterminal domain (CTD) of RNA polymerase II itself (10). Early studies in lymphocytes showed that cellular activation resulted in rapid changes, suggesting that $O$-GlcNAc cycled like phosphorylation and could be a regulatory modification (11), which was later confirmed by the sugar's rapid cycling on small heat shock proteins, shown by classical pulse-chase analyses (12). An assay for $O$-GlcNAc transferase (OGT), based upon tritiated UDP-GlcNAc as the donor and synthetic peptide acceptors, was developed and
OGT activity was identified and characterized (13). OGT was subsequently purified to apparent homogeneity by brute-force biochemical approaches combined with nucleotide affinity chromatography (14). O-GlcNAcase was originally purified from rat spleen cytosol (15) and was found to be similar to hexosaminidase C $(16,17)$, which was known but had not been purified to homogeneity. Based upon polypeptide sequencing, in conjunction with PCR cloning, the OGT cDNA from rat (18), C. elegans and human (19) were cloned. OGT was found to be a very highly conserved protein with no homology to other known glycosyltransferases. OGT was also found to have two distinct domains, a catalytic domain and a protein-protein interaction domain consisting of over 11 tetratricopeptide (TPR) repeats separated by a linker region. Likewise, O-GlcNAcase was purified from bovine brain and the protein was sequenced by mass spectrometry, and used to clone the enzyme from a human library (20). The OGA gene was found to be identical to MGEA5 a putative hyaluronidase associated with meningioma (21). Early studies identified $O$-GlcNAc on nuclear receptors, tau protein in the brain, intermediate filament proteins, nuclear oncogenes and tumor suppressors, and many other proteins with a wide-range of functions [reviewed in Ref. (22)].

\section{MORE RECENT FINDINGS}

As the tools for the detection and analysis of O-GlcNAcylation improved, it became apparent that this post-translational modification is much more abundant than previously expected [reviewed in Ref. $(23,24)]$. In addition, it was soon realized that not only was 
the donor for O-GlcNAcylation, UDP-GlcNAc, a major node of metabolism, but also that $O$-GlcNAc has extensive interplay with protein phosphorylation [reviewed in Ref. (23)]. Gene deletion studies have shown that both OGT and O-GlcNAcase are essential genes in mammals and plants (25-27).

Like phosphorylation and ubquitination, O-GlcNAcylation regulates many different cellular processes. O-GlcNAcylation is essential in the process of lymphocyte activation in both B- and T-lymphocytes (28). There are several examples where the glycan regulates protein:protein interactions [e.g., Ref. $(29,30)]$. Nutrients fine-tune circadian clocks via O-GlcNAcylation (31-34). OGlcNAc modulates the activity of the proteasome (35-39), and also has interplay with ubquitination $(40,41)$. Recent studies indicate that O-GlcNAcylation is very important to neuronal and brain functions, including synaptic plasticity, synaptic vesicle trafficking, and axonal branching (42-46). O-GlcNAcylation also regulates growth hormone signaling in plants (27), protects cells from acute stresses (47), and modulates transition through the cell cycle (48). Even though O-GlcNAcylation has not yet been documented to occur in yeast, such as Saccharomyces cerevisiae or Schizosaccharomyces pombe, O-GlcNAc does occur in some of oldest known eukaryotes (49), including in some important human parasites (50-52). In certain bacteria, O-GlcNAcylation regulates flagellar motility (53), and in Streptococcus pneumonia, O-GlcNAcylation of an adhesion plays a role in infection and pathogenesis (54). However, the bacterial OGT involved in each case is quite different from the eukaryotic enzyme.

As a key nutrient sensor, O-GlcNAcylation is fundamentally important to the regulation of transcription at nearly all levels, including regulation of the functions of RNA polymerase II itself $(55,56)$, modulating the activities of nearly all transcription factors (30), regulating both histone and DNA methylation (57-61), crosstalking with other epigenetic modifications (62), and serving as an integral part of the histone code (63). Not only does O-GlcNAcylation have extensive crosstalk with protein phosphorylation at the protein site level but also the sugar modifies many kinases and regulates their activities or specificity (64-69).

Given the myriad functions associated with O-GlcNAcylation, it is not surprising that this nutrient sensor plays a fundamental role in the etiology of diabetes and glucose toxicity (70-72). O-GlcNAcylation is elevated in all cancers studied to date and appears to play a role in tumor cell progression $(24,73,74)$, and in patient prognosis (75). Given O-GlcNAcylation's abundance and presence on hundreds of proteins in the brain, it is also a major mechanism contributing to neurodegeneration (76-78). After 30years of research on O-GlcNAcylation, it is now not only more apparent than ever that this post-translation modification plays a central role in the nutrient regulation of cellular physiology but also it is clear that we have a long way to go to fully understand the importance of O-GlcNAcylation in most cellular and disease processes.

\section{FUTURE DIRECTIONS}

Many important questions remain with respect to $\mathrm{O}$ GlcNAcylation. (1) How does O-GlcNAc cycling achieve substrate specificity with only two known genes in mammals, OGT and OGA (MGEA5)? Clearly, several different mechanisms are involved. In vitro, OGT has remarkable specificity for peptide subtrates, which appears to change with UDP-GlcNAc concentrations (79). Most importantly, both enzymes function as part of transient holoenzyme complexes, which number in the hundreds, are cell type specific and serve to target the enzymes to their specific substrates. A key question is how is the formation of these holoenzyme complexes regulated by nutrients and other signals? (2) How are kinases regulated by O-GlcNAcylation? Many kinases are dynamically O-GlcNAcylated, and thus far, those studied are regulated by the glycan. How does this observation alter our view of signaling and system biological studies of cellular physiology? (3) How does O-GlcNAcylation play a role in neuronal functions and in learning and memory? O-GlcNAcylation is incredibly abundant in the mammalian brain, and in neurons, particularly at the synapse and in dendritic spines $(42,45,80)$. Elucidation of $O$-GlcNAc's roles in normal neuronal functions and in brain biology will become a huge area of future research. (4) What are the specific roles of O-GlcNAcylation in nutrient regulation of transcription? While it is now clear that O-GlcNAcylation is fundamentally important in nearly every aspect of transcription, we currently know almost nothing with respect to its protein-specific or site-specific roles on individual transcription regulatory proteins. This area will remain an enormous challenge for some time to come.

Finally, while the tools to study O-GlcNAcylation have advanced substantially in the last three decades, there remains an acute need to develop better methods and approaches that can be applied by biologists. These include: (1) The development of many site-specific $O$-GlcNAc antibodies; (2) A molecular biology approach to either mimic O-GlcNAcylation or to generate site-specific O-GlcNAcylation on proteins; (3) Methods are need that can raise or lower O-GlcNAcylation on individual proteins or at individual sites to evaluate functions. Unfortunately, current methods either based upon inhibitors or genetic approaches to alter O-GlcNAcylation, all act globally. (5) There continues to be a need for better methods to both detect and site-map O-GlcNAc on proteins. The challenges in this field are large but so is the pay off for our understanding of cellular physiology and chronic disease.

\section{REFERENCES}

1. Torres C-R, Hart GW. Topography and polypeptide distribution of terminal Nacetylglucosamine residues on the surfaces of intact lymphocytes. J Biol Chem (1984) 259:3308-17.

2. Holt GD, Hart GW. The subcellular distribution of terminal Nacetylglucosamine moieties. Localization of a novel protein-saccharide linkage, O-linked GlcNAc. J Biol Chem (1986) 261:8049-57.

3. Hanover JA, Cohen CK, Willingham MC, Park MK. O-linked Nacetylglucosamine is attached to proteins of the nuclear pore. Evidence for cytoplasmic and nucleoplasmic glycoproteins. J Biol Chem (1987) 262:9887-94.

4. Davis LI, Blobel G. Nuclear pore complex contains a family of glycoproteins that includes p62: glycosylation through a previously unidentified cellular pathway. Proc Natl Acad Sci U S A (1987) 84:7552-6. doi:10.1073/pnas.84.21.7552

5. Holt GD, Snow CM, Senior A, Haltiwanger RS, Gerace L, Hart GW. Nuclear pore complex glycoproteins contain cytoplasmically disposed O-linked Nacetylglucosamine. J Cell Biol (1987) 104:1157-64. doi:10.1083/jcb.104.5.1157

6. Holt GD, Haltiwanger RS, Torres CR, Hart GW. Erythrocytes contain cytoplasmic glycoproteins. O-linked GlcNAc on Band 4.1. J Biol Chem (1987) 262:14847-50.

7. Benko DM, Haltiwanger RS, Hart GW, Gibson W. Virion basic phosphoprotein from human cytomegalovirus contains O-linked N-acetylglucosamine. Proc Natl Acad Sci U S A (1988) 85:2573-7. doi:10.1073/pnas.85.8.2573 
8. Kelly WG, Hart GW. Glycosylation of chromosomal proteins: localization of Olinked N-acetylglucosamine in Drosophila chromatin. Cell (1989) 57:243-51. doi:10.1016/0092-8674(89)90962-8

9. Jackson SP, Tjian R. O-glycosylation of eukaryotic transcription factors: implications for mechanisms of transcriptional regulation. Cell (1988) 55:125-33. doi:10.1016/0092-8674(88)90015-3

10. Kelly WG, Dahmus ME, Hart GW. RNA polymerase II is a glycoprotein. Modification of the COOH-terminal domain by O-GlcNAc. J Biol Chem (1993) 268:10416-24.

11. Kearse KP, Hart GW. Lymphocyte activation induces rapid changes in nuclear and cytoplasmic glycoproteins. Proc Natl Acad Sci U S A (1991) 88:1701-5. doi:10.1073/pnas.88.5.1701

12. Roquemore EP, Chevrier MR, Cotter RJ, Hart GW. Dynamic O-GlcNAcylation of the small heat shock protein alpha B-crystallin. Biochemistry (1996) 35:3578-86. doi:10.1021/bi951918j

13. Haltiwanger RS, Holt GD, Hart GW. Enzymatic addition of O-GlcNAc to nuclear and cytoplasmic proteins. Identification of a uridine diphospho-Nacetylglucosamine:peptide beta-N-acetylglucosaminyltransferase. J Biol Chem (1990) 265:2563-8.

14. Haltiwanger RS, Blomberg MA, Hart GW. Glycosylation of nuclear and cytoplasmic proteins. Purification and characterization of a uridine diphospho$\mathrm{N}$-acetylglucosamine:polypeptide beta- $\mathrm{N}$-acetylglucosaminyltransferase. J Biol Chem (1992) 267:9005-13.

15. Dong DL, Hart GW. Purification and characterization of an O-GlcNAc selective N-acetyl-beta-D-glucosaminidase from rat spleen cytosol. J Biol Chem (1994) 269:19321-30.

16. Overdijk B, Van der Kroef WM, Van Steijn GJ, Lisman JJ. Isolation and further characterization of bovine brain hexosaminidase C. Biochim Biophys Acta (1981) 659:255-66. doi:10.1016/0005-2744(81)90052-8

17. Braidman I, Carroll M, Dance N, Robinson D, Poenaru L, Weber A, et al. Characterisation of human N-acetyl-beta-hexosaminidase C. FEBS Lett (1974) 41:181-4. doi:10.1016/0014-5793(74)81206-8

18. Kreppel LK, Blomberg MA, Hart GW. Dynamic glycosylation of nuclear and cytosolic proteins. Cloning and characterization of a unique O-GlcNAc transferase with multiple tetratricopeptide repeats. J Biol Chem (1997) 272:9308-15. doi:10.1074/jbc.272.14.9308

19. Lubas WA, Frank DW, Krause M, Hanover JA. O-linked GlcNAc transferase is a conserved nucleocytoplasmic protein containing tetratricopeptide repeats. JBiol Chem (1997) 272:9316-24. doi:10.1074/jbc.272.14.9316

20. Gao Y, Wells L, Comer FI, Parker GJ, Hart GW. Dynamic O-glycosylation of nuclear and cytosolic proteins: cloning and characterization of a neutral, cytosolic beta-N-acetylglucosaminidase from human brain. J Biol Chem (2001) 276:9838-45. doi:10.1074/jbc.M010420200

21. Comtesse N, Maldener E, Meese E. Identification of a nuclear variant of MGEA5, a cytoplasmic hyaluronidase and a beta- $\mathrm{N}$-acetylglucosaminidase. Biochem Biophys Res Commun (2001) 283:634-40. doi:10.1006/bbrc.2001.4815

22. Hart GW. Dynamic O-linked glycosylation of nuclear and cytoskeletal proteins. Ann Rev Biochem (1997) 66:315-35. doi:10.1146/annurev.biochem.66.1.315

23. Hart GW, Slawson C, Ramirez-Correa G, Lagerlof O. Cross talk between O-GlcNAcylation and phosphorylation: roles in signaling, transcription, and chronic disease. Annu Rev Biochem (2011) 80:825-58. doi:10.1146/annurevbiochem-060608-102511

24. Hardiville S, Hart GW. Nutrient regulation of signaling, transcription, and cell physiology by O-GlcNAcylation. Cell Metab (2014) 20:208-13. doi:10.1016/j. cmet.2014.07.014

25. Shafi R, Iyer SP, Ellies LG, O'Donnell N, Marek KW, Chui D, et al. The OGlcNAc transferase gene resides on the $\mathrm{X}$ chromosome and is essential for embryonic stem cell viability and mouse ontogeny. Proc Natl Acad Sci U S A (2000) 97:5735-9. doi:10.1073/pnas.100471497

26. Hartweck LM, Scott CL, Olszewski NE. Two O-linked N-acetylglucosamine transferase genes of Arabidopsis thaliana L. Heynh. have overlapping functions necessary for gamete and seed development. Genetics (2002) 161:1279-91.

27. Olszewski NE, West CM, Sassi SO, Hartweck LM. O-GlcNAc protein modification in plants: evolution and function. Biochim Biophys Acta (2010) 1800:49-56. doi:10.1016/j.bbagen.2009.11.016

28. Golks A, Tran TT, Goetschy JF, Guerini D. Requirement for O-linked Nacetylglucosaminyltransferase in lymphocytes activation. EMBO J (2007) 26:4368-79. doi:10.1038/sj.emboj.7601845
29. Hiromura M, Choi CH, Sabourin NA, Jones H, Bachvarov D, Usheva A. YY1 is regulated by O-linked $\mathrm{N}$-acetylglucosaminylation (O-glcNAcylation). J Biol Chem (2003) 278:14046-52. doi:10.1074/jbc.M300789200

30. Ozcan S, Andrali SS, Cantrell JE. Modulation of transcription factor function by O-GlcNAc modification. Biochim Biophys Acta (2010) 1799:353-64. doi:10.1016/j.bbagrm.2010.02.005

31. Durgan DJ, Pat BM, Laczy B, Bradley JA, Tsai JY, Grenett MH, et al. O-GlcNAcylation, novel post-translational modification linking myocardial metabolism and cardiomyocyte circadian clock. J Biol Chem (2011) 286:44606-19. doi:10.1074/jbc.M111.278903

32. Kim EY, Jeong EH, Park S, Jeong HJ, Edery I, Cho JW. A role for OGlcNAcylation in setting circadian clock speed. Genes Dev (2012) 26:490-502. doi:10.1101/gad.182378.111

33. Kaasik K, Kivimae S, Allen JJ, Chalkley RJ, Huang Y, Baer K, et al. Glucose sensor O-GlcNAcylation coordinates with phosphorylation to regulate circadian clock. Cell Metab (2013) 17:291-302. doi:10.1016/j.cmet.2012.12.017

34. Hart GW. How sugar tunes your clock. Cell Metab (2013) 17:155-6. doi:10. 1016/j.cmet.2013.01.008

35. Sumegi M, Hunyadi-Gulyas E, Medzihradszky KF, Udvardy A. 26 S proteasome subunits are O-linked $\mathrm{N}$-acetylglucosamine-modified in Drosophila melanogaster. Biochem Biophys Res Commun (2003) 312:1284-9. doi:10.1016/j. bbrc.2003.11.074

36. Liu K, Paterson AJ, Zhang F, McAndrew J, Fukuchi K, Wyss JM, et al. Accumulation of protein O-GlcNAc modification inhibits proteasomes in the brain and coincides with neuronal apoptosis in brain areas with high O-GlcNAc metabolism. J Neurochem (2004) 89:1044-55. doi:10.1111/j.1471-4159.2004.02389.x

37. Kudlow JE. Post-translational modification by O-GlcNAc: another way to change protein function. J Cell Biochem (2006) 98:1062-75. doi:10.1002/jcb. 20926

38. Bowe DB, Sadlonova A, Toleman CA, Novak Z, Hu Y, Huang P, et al. O-GlcNAc integrates the proteasome and transcriptome to regulate nuclear hormone receptors. Mol Cell Biol (2006) 26:8539-50. doi:10.1128/MCB.01053-06

39. Zhang F, Su K, Yang X, Bowe DB, Paterson AJ, Kudlow JE. O-GlcNAc modification is an endogenous inhibitor of the proteasome. Cell (2003) 115:715-25. doi:10.1016/S0092-8674(03)00974-7

40. Guinez C, Mir AM, Dehennaut V, Cacan R, Harduin-Lepers A, Michalski JC, et al. Protein ubiquitination is modulated by O-GlcNAc glycosylation. FASEB J (2008) 22:2901-11. doi:10.1096/fj.07-102509

41. Ruan HB, Nie Y, Yang X. Regulation of protein degradation by O-GlcNAcylation: crosstalk with ubiquitination. Mol Cell Proteomics (2013) 12:3489-97. doi:10. 1074/mcp.R113.029751

42. Tallent MK, Varghis N, Skorobogatko Y, Hernandez-Cuebas L, Whelan K, Vocadlo DJ, et al. In vivo modulation of O-GlcNAc levels regulates hippocampal synaptic plasticity through interplay with phosphorylation. J Biol Chem (2009) 284:174-81. doi:10.1074/jbc.M807431200

43. Francisco H, Kollins K, Varghis N, Vocadlo D, Vosseller K, Gallo G. O-GLcNAc post-translational modifications regulate the entry of neurons into an axon branching program. Dev Neurobiol (2009) 69:162-73. doi:10.1002/dneu.20695

44. Skorobogatko Y, Landicho A, Chalkley RJ, Kossenkov AV, Gallo G, Vosseller K. O-linked beta-N-acetylglucosamine (O-GlcNAc) site thr-87 regulates synapsin I localization to synapses and size of the reserve pool of synaptic vesicles. J Biol Chem (2014) 289:3602-12. doi:10.1074/jbc.M113.512814

45. Vosseller K, Trinidad JC, Chalkley RJ, Specht CG, Thalhammer A, Lynn AJ, et al. O-linked $\mathrm{N}$-acetylglucosamine proteomics of postsynaptic density preparations using lectin weak affinity chromatography and mass spectrometry. Mol Cell Proteomics (2006) 5:923-34. doi:10.1074/mcp.T500040-MCP200

46. Trinidad JC, Barkan DT, Gulledge BF, Thalhammer A, Sali A, Schoepfer R, et al. Global identification and characterization of both O-GlcNAcylation and phosphorylation at the murine synapse. Mol Cell Proteomics (2012) 11:215-29. doi:10.1074/mcp.O112.018366

47. Zachara NE, O'Donnell N, Cheung WD, Mercer JJ, Marth JD, Hart GW. Dynamic O-GlcNAc modification of nucleocytoplasmic proteins in response to stress. A survival response of mammalian cells. J Biol Chem (2004) 279:30133-42. doi:10.1074/jbc.M403773200

48. Slawson C, Zachara NE, Vosseller K, Cheung WD, Lane MD, Hart GW. Perturbations in $\mathrm{O}$-linked beta-N-acetylglucosamine protein modification cause severe defects in mitotic progression and cytokinesis. J Biol Chem (2005) 280:32944-56. doi:10.1074/jbc.M503396200 
49. Banerjee S, Robbins PW, Samuelson J. Molecular characterization of nucleocytosolic O-GlcNAc transferases of Giardia lamblia and Cryptosporidium parvum. Glycobiology (2009) 19:331-6. doi:10.1093/glycob/cwn107

50. Acosta DM, Soprano LL, Ferrero M, Landoni M, Esteva MI, Couto AS, et al. A striking common O-linked $\mathrm{N}$-acetylglucosaminyl moiety between cruzipain and myosin. Parasite Immunol (2011) 33:363-70. doi:10.1111/j.1365-3024.2011. 01291.x

51. Perez-Cervera Y, Harichaux G, Schmidt J, Debierre-Grockiego F, Dehennaut V, Bieker U, et al. Direct evidence of O-GlcNAcylation in the apicomplexan Toxoplasma gondii: a biochemical and bioinformatic study. Amino Acids (2011) 40:847-56. doi:10.1007/s00726-010-0702-4

52. Uddin N, Hoessli DC, Butt A, Kaleem A, Iqbal Z, Afzal I, et al. O-GlcNAc modification of the anti-malarial vaccine candidate PfAMA1: in silico-defined structural changes and potential to generate a better vaccine. Mol Biol Rep (2012) 39:4663-72. doi:10.1007/s11033-011-1258-4

53. Shen A, Kamp HD, Grundling A, Higgins DE. A bifunctional O-GlcNAc transferase governs flagellar motility through anti-repression. Genes Dev (2006) 20:3283-95. doi:10.1101/gad.1492606

54. Shi WW, Jiang YL, Zhu F, Yang YH, Shao QY, Yang HB, et al. Structure of a novel O-linked N-acetyl-D-glucosamine (O-GlcNAc) transferase, GtfA, reveals insights into the glycosylation of pneumococcal serinerich repeat adhesins. J Biol Chem (2014) 289:20898-907. doi:10.1074/jbc.M114. 581934

55. Lewis BA. O-GlcNAcylation at promoters, nutrient sensors, and transcriptional regulation. Biochim Biophys Acta (2013) 1829:1202-6. doi:10.1016/j.bbagrm. 2013.09.003

56. Ranuncolo SM, Ghosh S, Hanover JA, Hart GW, Lewis BA. Evidence of the involvement of O-GlcNAc-modified human RNA polymerase II CTD in transcription in vitro and in vivo. J Biol Chem (2012) 287:23549-61. doi:10.1074/ jbc.M111.330910

57. Chen Q, Chen Y, Bian C, Fujiki R, Yu X. TET2 promotes histone OGlcNAcylation during gene transcription. Nature (2013) 493:561-4. doi:10. 1038/nature11742

58. Deplus R, Delatte B, Schwinn MK, Defrance M, Mendez J, Murphy N, et al. TET2 and TET3 regulate GlcNAcylation and H3K4 methylation through OGT and SET1/COMPASS. EMBO J (2013) 32:645-55. doi:10.1038/emboj. 2012.357

59. Shi FT, Kim H, Lu W, He Q, Liu D, Goodell MA, et al. Ten-eleven translocation 1 (Tet1) is regulated by O-linked $\mathrm{N}$-acetylglucosamine transferase (Ogt) for target gene repression in mouse embryonic stem cells. J Biol Chem (2013) 288:20776-84. doi:10.1074/jbc.M113.460386

60. Zhang Q, Liu X, Gao W, Li P, Hou J, Li J, et al. Differential regulation of the ten-eleven translocation (TET) family of dioxygenases by O-linked beta$\mathrm{N}$-acetylglucosamine transferase (OGT). J Biol Chem (2014) 289:5986-96. doi:10.1074/jbc.M113.524140

61. Fujiki R, Chikanishi T, Hashiba W, Ito H, Takada I, Roeder RG, et al. GlcNAcylation of a histone methyltransferase in retinoic-acid-induced granulopoiesis. Nature (2009) 459:455-9. doi:10.1038/nature07954

62. Sakabe K, Hart GW. O-GlcNAc transferase regulates mitotic chromatin dynamics. J Biol Chem (2010) 285:34460-8. doi:10.1074/jbc.M110.158170

63. Sakabe K, Wang Z, Hart GW. Beta-N-acetylglucosamine (O-GlcNAc) is part of the histone code. Proc Natl Acad Sci U S A (2010) 107:19915-20. doi:10.1073/ pnas. 1009023107

64. Bullen JW, Balsbaugh JL, Chanda D, Shabanowitz J, Hunt DF, Neumann D, et al. Cross-talk between two essential nutrient-sensitive enzymes: O-GlcNAc transferase (OGT) and AMP-activated protein kinase (AMPK). J Biol Chem (2014) 289:10592-606. doi:10.1074/jbc.M113.523068

65. Erickson JR, Pereira L, Wang L, Han G, Ferguson A, Dao K, et al. Diabetic hyperglycaemia activates CaMKII and arrhythmias by O-linked glycosylation. Nature (2013) 502:372-6. doi:10.1038/nature12537
66. Yi W, Clark PM, Mason DE, Keenan MC, Hill C, Goddard WA III, et al. Phosphofructokinase 1 glycosylation regulates cell growth and metabolism. Science (2012) 337:975-80. doi:10.1126/science.1222278

67. Tarrant MK, Rho HS, Xie Z, Jiang YL, Gross C, Culhane JC, et al. Regulation of CK2 by phosphorylation and O-GlcNAcylation revealed by semisynthesis. Nat Chem Biol (2012) 8:262-9. doi:10.1038/nchembio.771

68. Dias WB, Cheung WD, Hart GW. O-GlcNAcylation of kinases. Biochem Biophys Res Commun (2012) 422:224-8. doi:10.1016/j.bbrc.2012.04.124

69. Dias WB, Cheung WD, Wang Z, Hart GW. Regulation of calcium/calmodulindependent kinase IV by O-GlcNAc modification. J Biol Chem (2009) 284:21327-37. doi:10.1074/jbc.M109.007310

70. Slawson C, Copeland RJ, Hart GW. O-GlcNAc signaling: a metabolic link between diabetes and cancer? Trends Biochem Sci (2010) 35:547-55. doi:10. 1016/j.tibs.2010.04.005

71. Lefebvre T, Dehennaut V, Guinez C, Olivier S, Drougat L, Mir AM, et al. Dysregulation of the nutrient/stress sensor O-GlcNAcylation is involved in the etiology of cardiovascular disorders, type-2 diabetes and Alzheimer's disease. Biochim Biophys Acta (2010) 1800:67-79. doi:10.1016/j.bbagen.2009.08.008

72. Hanover JA, Krause MW, Love DC. The hexosamine signaling pathway: OGlcNAc cycling in feast or famine. Biochim Biophys Acta (2010) 1800:80-95. doi:10.1016/j.bbagen.2009.07.017

73. Ma Z, Vosseller K. Cancer metabolism and elevated O-GlcNAc in oncogenic signaling. J Biol Chem (2014) 289.

74. Ma Z, Vosseller K. O-GlcNAc in cancer biology. Amino Acids (2013) 45:719-33. doi:10.1007/s00726-013-1543-8

75. Shi Y, Tomic J, Wen F, Shaha S, Bahlo A, Harrison R, et al. Aberrant OGlcNAcylation characterizes chronic lymphocytic leukemia. Leukemia (2010) 24:1588-98. doi:10.1038/leu.2010.152

76. Lazarus BD, Love DC, Hanover JA. O-GlcNAc cycling: implications for neurodegenerative disorders. Int J Biochem Cell Biol (2009) 41:2134-46. doi:10.1016/j. biocel.2009.03.008

77. Yuzwa SA, Vocadlo DJ. O-GlcNAc and neurodegeneration: biochemical mechanisms and potential roles in Alzheimer's disease and beyond. Chem Soc Rev (2014) 43:6839-58. doi:10.1039/c4cs00038b

78. Lagerlof O, Hart GW. O-GlcNAcylation of neuronal proteins: roles in neuronal functions and in neurodegeneration. Adv Neurobiol (2014) 9:343-66. doi:10.1007/978-1-4939-1154-7_16

79. Kreppel LK, Hart GW. Regulation of a cytosolic and nuclear O-GlcNAc transferase. Role of the tetratricopeptide repeats. J Biol Chem (1999) 274:32015-22. doi:10.1074/jbc.274.45.32015

80. Cole RN, Hart GW. Cytosolic O-glycosylation is abundant in nerve terminals. $J$ Neurochem (2001) 79:1080-9. doi:10.1046/j.1471-4159.2001.00655.x

Conflict of Interest Statement: The author declares that the research was conducted in the absence of any commercial or financial relationships that could be construed as a potential conflict of interest.

Received: 24 September 2014; accepted: 10 October 2014; published online: 27 October 2014.

Citation: Hart GW (2014) Three decades of research on O-GlcNAcylation - a major nutrient sensor that regulates signaling, transcription and cellular metabolism. Front. Endocrinol. 5:183. doi: 10.3389/fendo.2014.00183

This article was submitted to Molecular and Structural Endocrinology, a section of the journal Frontiers in Endocrinology.

Copyright (C) 2014 Hart. This is an open-access article distributed under the terms of the Creative Commons Attribution License (CC BY). The use, distribution or reproduction in other forums is permitted, provided the original author(s) or licensor are credited and that the original publication in this journal is cited, in accordance with accepted academic practice. No use, distribution or reproduction is permitted which does not comply with these terms. 